\title{
PCM1/RET Fusion Gene
}

National Cancer Institute

\section{Source}

National Cancer Institute. PCM1/RET Fusion Gene. NCI Thesaurus. Code C99399.

A fusion gene that results from a chromosomal translocation $\mathrm{t}(8 ; 10)(\mathrm{p} 21.3 ; \mathrm{q} 11.2)$ which fuses the 5' portion of the PCM1 gene to the 3' portion of the RET gene. This rearrangement is associated with papillary thyroid carcinoma. 